\title{
Meta
}

Journal des traducteurs

Translators' Journal

\section{Presuppositions in Literary Translation: A Corpus-Based Approach}

\section{Adriana Şerban}

Volume 49, numéro 2, juin 2004

URI : https://id.erudit.org/iderudit/009355ar

DOI : https://doi.org/10.7202/009355ar

Aller au sommaire du numéro

Éditeur(s)

Les Presses de l'Université de Montréal

ISSN

0026-0452 (imprimé)

1492-1421 (numérique)

Découvrir la revue

Citer cet article

Serban, A. (2004). Presuppositions in Literary Translation: A Corpus-Based Approach. Meta, 49(2), 327-342. https://doi.org/10.7202/009355ar
Résumé de l'article

La présente étude a pour objet d'examiner l'usage des présuppositions existentielles dans un corpus de traductions vers l'anglais de textes littéraires roumains (romans et nouvelles). Plus exactement, on se donne pour tâche de découvrir d'éventuelles différences entre l'usage des articles définis et indéfinis dans les textes de départ et les textes-cibles, et d'étudier de possibles glissements systématiques. L'étude conclut que la tendance prédominante dans le corpus est vers l'utilisation des articles indéfinis, et que cette tendance est liée à la distanciation: les lecteurs des traductions se trouvent positionnés, par les textes, comme des observateurs éloignés.
Ce document est protégé par la loi sur le droit d'auteur. L'utilisation des services d'Érudit (y compris la reproduction) est assujettie à sa politique d'utilisation que vous pouvez consulter en ligne.

https://apropos.erudit.org/fr/usagers/politique-dutilisation/ 


\title{
Presuppositions in Literary Translation: A Corpus-Based Approach
}

\author{
ADRIANA ŞERBAN \\ University of Leeds, Leeds, United Kingdom \\ a.serban@leeds.ac.uk
}

\begin{abstract}
RÉSUMÉ
La présente étude a pour objet d'examiner l'usage des présuppositions existentielles dans un corpus de traductions vers l'anglais de textes littéraires roumains (romans et nouvelles). Plus exactement, on se donne pour tâche de découvrir d'éventuelles différences entre l'usage des articles définis et indéfinis dans les textes de départ et les textescibles, et d'étudier de possibles glissements systématiques. L'étude conclut que la tendance prédominante dans le corpus est vers l'utilisation des articles indéfinis, et que cette tendance est liée à la distanciation: les lecteurs des traductions se trouvent positionnés, par les textes, comme des observateurs éloignés.
\end{abstract}

\section{ABSTRACT}

This paper investigates the use of existential presuppositions in a corpus of literary translations from Romanian into English (novels and short stories). In particular, we are interested in ascertaining whether there are any differences between the ways in which definiteness and indefiniteness are used in translations compared to source texts, and whether any pattern can be found to be in operation; the aim is to explore presuppositions in terms of what they can tell us about translators' assumptions about their readers. The main finding is the presence of a [- definite] trend in the corpus, whereby definite references tend to be translated by indefinite references. The study suggests that this is linked to distancing; i.e., target readers are presented with texts which position them as distant observers, rather than in-the-know in-group members.

\section{MOTS-CLÉS/KEYWORDS}

discourse, literary corpus, presupposition, Romanian

\section{Introduction}

The term presupposition refers to those assumptions which appear to be built into the linguistic structure of texts and which relate linguistic structure to extra-linguistic context in terms of the inferences which are expected to be made about this context (Levinson 1983: 68). As pointed out by Yule (1996), "speakers continually design their linguistic messages on the basis of assumptions about what their hearers already know [...]. What a speaker assumes is true or is known by the hearer can be described as a presupposition" (Yule 1996: 131-2). Presuppositions are extremely sensitive to context, and thus differ from logical entailment, which refers to those inferences which can be made strictly from linguistic expression itself and are restricted to the truthconditions of the particular expression. Since they are "background assumptions against which an action, theory, expression or utterance makes sense or is rational" (Levinson 1983: 168), presuppositions are a middle ground between tacitly assuming 
that something does not need to be mentioned at all, and, on the other hand, asserting it explicitly, perhaps as a separate statement.

Prince (1981) notes that there is considerable disagreement between researchers investigating the notions of given versus new information (or old-new, known-new, presupposition-focus, which are some of the aliases of given-new). Thus, 'given' is sometimes used in the sense of 'predictability and recoverability,' or 'saliency,' or 'shared knowledge.' The latter notion is particularly problematic because, in the absence of conclusive evidence as to what other people's knowledge or beliefs could be, a communicator can only make (more or less informed) assumptions about such knowledge, beliefs, or information. Along the same lines, 'common knowledge' and 'shared/mutual knowledge or information' have been shown (by Sperber and Wilson 1986) to be imprecise since one can only make assumptions about what may be 'mutually manifest,' or about the extent to which people share our cognitive environment (see 2.2.3.3). Prince (1981) proposes the term 'assumed familiarity', and proceeds to suggest a number of categories of given-new information. Her taxonomy includes three main categories, namely 'new,' 'inferrable,' and 'evoked.' There are further subdivisions to these categories, for example 'new' comprises 'brand-new' and 'unused,' whereas 'evoked' can be 'textually evoked' or 'situationally evoked.' The category of the 'inferrables' is, according to Prince (1981: 242), linked to stereotypic assumptions such as 'Houses have doors'; such assumptions may differ to various extents from one culture to another.

Levinson (2000: 94) presents a hierarchy of givenness of anaphoric expressions in English, according to the degree to which their referents are mentally activated. Interestingly, this scale includes definite and indefinite reference and the deictics 'that' and 'this.' Starting from the left of the scale and proceeding to the right, the following categories are suggested: 'type-identifiable' (indefinite reference), 'uniquely identifiable' (definite reference), 'familiar' (the distal deictic 'that'), 'activated' (both 'that' and 'this' can be used, although not interchangeably), and, finally, 'in-focus' (e.g. 'it'). In this scale, rightwards expressions have more precise criteria of application than leftwards expressions; consequently, using a leftwards expression to refer to an entity implicates that the communicator could not have felicitously referred to this entity by using an expression higher on the scale. For example, 'the' suggests that the entity referred to is uniquely identifiable, whereas ' $a$ ' is unmarked in this respect and therefore picks up the complementary interpretation; since 'a' has a wider distribution than 'the,' opting for 'the' rather than 'a' generates an implicature.

The presence of a presupposition is usually signalled by particular words or aspects of surface structure in general, which are called presupposition triggers. Levinson (1983: 181-4) lists a number of thirteen such triggers, including definite descriptions (e.g. 'John saw the man with two heads' presupposes that there exists a man with two heads), iteratives (e.g. 'The flying saucer came again' presupposes that it had come before), change of state verbs (e.g. 'Peter stopped visiting his parents' presupposes that he had been visiting his parents). Our investigation of presuppositions in English translations of Romanian literary texts will primarily focus on presuppositions triggered by definite description. More particularly, we shall focus on presuppositions triggered by the use of definite articles, which are also known as 'existential presuppositions' (Simpson 1993: 125).

Table 1 below presents the definite and indefinite articles in Romanian and English. 
TABLE 1

Romanian and English articles

\begin{tabular}{|l|l|l|}
\hline Articles & Romanian & English \\
\hline Definite & $\begin{array}{l}\text {-a (f, sg.), -ul (m, sg) } \\
\text {-le (f, pl.), -i (m, pl.) }\end{array}$ & the \\
\hline Indefinite & $\begin{array}{l}\text { o (f), un (m) } \\
\text { niște (f and } \mathrm{m}, \mathrm{pl} .)\end{array}$ & $\begin{array}{l}\text { a, an } \\
\text { - the zero article }\end{array}$ \\
\hline
\end{tabular}

First of all, it must be noted that Romanian articles (much like articles in French, Spanish or Italian) are gender-specific, and there is a further distinction between singular and plural forms. The definite article, in Romanian, is enclitic rather than proclitic. Finally, there is no specific category, in Romanian, to parallel the so-called 'zero article' in English; this is considered to be part of the category of indefiniteness. In most respects, however, the basic distinction between definiteness (entities assumed to be known) and indefiniteness (entities assumed not to be known) is similar between the two languages.

Romanian and English grammars (e.g. Graur et al. 1966; Daniliuc and Daniliuc 2000; Leech 1989) concur in suggesting that definiteness should be used for pointing to specific referents, such as entities which both speaker and hearer know about (e.g. something which has been mentioned before can be assumed to be known, or to be familiar to the hearer), while the indefinite article signals a more or less unknown entity out of a range of similar ones, but without specifying which. The use of the zero article in English is also a form of indefiniteness. It is evident that these guidelines leave plenty of scope for using either form, because what may be assumed to be assumed by the interlocutor is highly subjective.

Some precise rules or conventions of usage do exist and are listed in grammars, but they tend to refer to several specific categories of nouns or to deal with exceptions. For instance, abstract notions are usually accompanied by a definite article in Romanian in sentences such as 'Frumusețea va salva lumea' (literal translation: The beauty will save the world), just as in French and other Romance languages, but in English the zero article is used: 'Beauty will save the world.' Along the same lines, definiteness is used in Romanian to designate generic reference (e.g. omenirea - literally, the mankind) or for seasons (vara - the summer), while English uses the zero article (mankind, summer). In such instances, shifting from definite to zero article would be obligatory in translation and this kind of shift is not part of the present inquiry, unless a translator breaks the rule and uses a dispreferred form for a specific reason or purpose.

Because presuppositions are context-sensitive, they are bound to be a problematic area of translation due to the fact that, in translating, the context of production and reception of the original text is replaced by the context of translation and publication of the target text. Usually spatio-temporal differences are involved, and the audience a translator addresses may be very different in terms of cognitive environment (world view, assumptions, expectations, and so on) from the readership of the original text. Our aim in what follows is to ascertain whether there are any differences between the pattern of definiteness and indefiniteness in translations com- 
pared to source texts, and to explore what this tells us about the translators' assumptions about readers; we are particularly interested in any trends which might be found to be in operation.

\section{Methodology}

The data analysed here are samples from a corpus of eleven literary translations from Romanian into English. The translations are novels and anthologies/individual volumes of short stories. The original works were all published between 1900 and 1989, and the translations into English appeared between 1945 and 1989 (the Communist period in Romania, a period of relative cultural isolation). All the translations were published by Romanian publishing houses and the translators were native users of Romanian translating into their foreign language (English). The translations are part of the Communist Party agenda of making Romanian cultural achievements known abroad; it is however doubtful whether many of the translations actually reached their target audiences. They were also commercialised in Romania and were used by Romanian teachers of English as language materials, since English native speaker material was scarcely available.

The corpus ${ }^{1}$ is comprehensive in that it includes all the translations that satisfy the following selection criteria: Romanian literature, prose only, novels and short-stories only; published for the first time in Romanian during the period 1900 to 1989; translated into English by Romanian natives during the Communist period in Romania and published by Romanian publishing houses. Samples of 4500 words were taken from each book (for a detailed discussion of sampling and representativity with specific reference to this project, see Şerban 2003: 50-5), and the use of definite and indefinite reference in source texts and translations investigated in both a quantitative, and a qualitative (pragmatics-oriented) way. In actual fact, due to the need to pay attention to text boundaries, the word count of individual samples is rarely an exact 4500 words; most samples are slightly longer, as the end of each sample was usually established at the first appropriate text boundary occurring after the 4500 word limit.

\section{Numerical findings}

Table 2 below presents the numerical findings which relate to the translation of articles in the eleven samples from our corpus. 
TABLE 2

Article shifts in the corpus

\begin{tabular}{|c|c|c|c|c|c|}
\hline No. & Title of TT & \multicolumn{2}{|c|}{$\begin{array}{l}\text { ST definite reference } \\
\text { to TT indefinite reference }\end{array}$} & \multicolumn{2}{|c|}{$\begin{array}{l}\text { TT adds extra def. reference } \\
\text { or translates indef. ref. as } \\
\text { definite }\end{array}$} \\
\hline $1 \mathrm{a}$ & RFT (Califar's Mill) & 5 & \multirow[b]{2}{*}{6} & 1 & \multirow[b]{2}{*}{1} \\
\hline $1 b$ & RFT (Remember) & 1 & & - & \\
\hline $2 \mathrm{a}$ & HL (Seven Horns) & 9 & \multirow[b]{3}{*}{13} & - & \multirow[b]{3}{*}{1} \\
\hline $2 b$ & HL (Şuer) & 2 & & - & \\
\hline $2 c$ & HL (Prince Cuza) & 2 & & 1 & \\
\hline 3 & A Man amongst Men & \multicolumn{2}{|r|}{4} & & 4 \\
\hline 4 & Gathering Clouds & \multicolumn{2}{|r|}{2} & & 1 \\
\hline 5 & The Stranger & \multicolumn{2}{|r|}{-} & & - \\
\hline 6 & The Morometes & \multicolumn{2}{|r|}{4} & & 2 \\
\hline 7 & Adam and Eve & \multicolumn{2}{|r|}{30} & & 6 \\
\hline $8 \mathrm{a}$ & ET (The First Thorn) & 4 & \multirow[b]{2}{*}{4} & 2 & \multirow[b]{2}{*}{6} \\
\hline $8 b$ & ET (Bee-Fold) & - & & 4 & \\
\hline 9 & The Golden Bough & & 16 & & 4 \\
\hline 10 & The Hatchet & & 18 & & 14 \\
\hline \multirow[t]{3}{*}{11} & TFM (Wolves) & & 23 & & 4 \\
\hline & TOTAL & & $\begin{array}{l}\quad 120 \\
\text { (73.62\% of all } \\
\text { article shifts) }\end{array}$ & & $\begin{array}{l}\quad 43 \\
\text { (26.38\% of all } \\
\text { article shifts) }\end{array}$ \\
\hline & & \multicolumn{4}{|c|}{163 article shifts in total } \\
\hline
\end{tabular}

As can be seen in Table 2, two main shift types are investigated. The first of them includes shifts from ST definite reference to TT indefinite reference (column 3). Target text additions of extra definite reference and shifts from ST indefinite reference to TT definite reference constitute the second shift type (column 4). Column 1 gives the number of each sample, and column 2 presents the title or an abbreviation of the title. The small case letters a, b, and c, which follow the number of some samples, indicate that the sample comprises several sections. Thus, $8 \mathrm{a}$ and $8 \mathrm{~b}$ are two short stories which together are sample 8 . In the case of such samples, shifts have been counted separately for each section and their sum is taken to be the overall number of shifts for the sample; for instance, there are two additions of definite reference in $8 \mathrm{a}$ and four such shifts in $8 \mathrm{~b}$ (column 4 ), therefore the number of shifts from indefinite to definite reference in sample 8 is six.

There are 120 shifts from definite to indefinite reference in the overall sample, and 43 shifts in the direction of increased definiteness; the number of shifts which increase indefiniteness is almost three times the number of reverse shifts. This evidence, combined with the fact that in all but one sample (8) the number of shifts towards the indefinite is higher than or at least equal (sample 3 ) to that of shifts towards the definite, suggests that the pattern of shifts involving articles in the overall 
sample is towards the indefinite. Sample 8 is the only exception to this; there are four shifts towards the indefinite and six shifts towards the definite there. In addition, there is one sample (3) in which the number of shifts towards the indefinite is equal to the number of shifts towards the definite. All the other samples adhere to the trend, but there is considerable variation in the number of occurrences which each of them contributes to and against the trend. To give an extreme example, there are only two shifts towards the indefinite in 4 , and as many as 30 such shifts in 7 . There is one sample (5) where no reference shifts occur at all, which points to the fact that, where shifts involving definite or indefinite reference do occur, a strong element of optionality is involved.

In conclusion, a preference towards indefinite [- definite] rather than definite [+ definite] shifting was found in the corpus sample. This does not mean that the translators shift every definite article towards an indefinite, but that, should a shift take place, it is more likely to be towards the indefinite ${ }^{2}$.

\section{Definiteness versus indefiniteness: existential presuppositions}

This section aims to explore a number of examples which illustrate the main pattern in the corpus, but will also analyse an instance which runs counter to the trend. It is particularly important at this point to see how definiteness and indefiniteness are used in the actual texts, and what they tell us about translators' assumptions about readers.

Our first example comes from a short story entitled Califar's Mill, by Gala Galaction. Originally published in 1902, Moara lui Călifar appeared in English translation in the 1981 volume Romanian Fantastic Tales translated by Ana Cartianu and published in Bucharest. As the title of the translated volume suggests, the story belongs to the literary genre of the fantastic. Călifar is a miller, and is said to be a wizard, a lost soul who serves the devil by leading other people to damnation. Young people from neighbouring villages are attracted by the promise of fortune he can bestow on them, but end up losing their minds and souls. Extract (1) is taken from the very beginning of the story, introducing the setting, and is the first contact (excepting the title) the audience has with the text. Because of this, the information readers are given at this point, and the way in which it is presented, are extremely relevant for our investigation of presuppositions as evidence of reader positioning.

(1)

ST: In preajma unei păduri străvechi se privea în iaz moara lui Călifar. Se privea de cînd se ținea minte în bătrînii satului din cealaltă margine a pădurii [...]. (Galaction 1979: 160)

Gloss: Near an ancient forest, was looking at itself [mirroring] in the pond Călifar's mill. It had been looking at itself [mirroring] for as long as the elders of the village from the other end of the forest could remember [...]

TT: On the borders of an ancient forest Califar's mill stood mirrored in the water of $\underline{\text { a }}$ pond. It had been thus looking into the water ever since the oldest villagers, on the far side of the forest, could remember [...]. (Galaction 1981: 48)

There are several presuppositions in (1), and ST and TT share most of them. Both of them presuppose, by using definite description and a possessive adjective, the existence of Călifar's mill (rather than presenting it as new information, which it actually 
is), as well as that of the village and its elders, at the other end of the forest. According to Prince's (1981) categories of 'assumed familiarity' (see section 1), Călifar, his mill, the forest, and the village are 'brand-new' information (even though presented as familiar), while the elders of the village are 'inferrable.' No clues are given, however, to link the location of the narrative with the world outside, with places a reader might identify - the village, forest, and the mill could be anywhere in the Romanian countryside. It is therefore unlikely that these presuppositions are used because readers are assumed to share the writer's awareness of the existence of the entities designated. Rather, they are an expression of the writer's commitment to the existence of the entities which are presupposed and, at the same time, a subtle way of making new information appear to be what readers should or are expected to take for granted (Yule 1996: 27-9). Such a procedure would not be unfamiliar to readers of fiction, as it is a conventional way of inviting readers to enter a fictional world.

The one instance in which ST and TT (1) differ in terms of how presupposition is handled is that in the Romanian definite description is used upon first mentioning the pond, while the translation features an indefinite article at that point. This presupposition is of a different kind from most presuppositions mentioned above, with the exception of 'the elders': it may be argued that usually mills have ponds and consequently the ST definite description does not presuppose the existence of the pond but rather assumes that readers with an elementary knowledge about mills will take the pond for granted once they have accepted the presupposition concerning the existence of the mill. To use Prince's (1981) framework, 'the pond' is 'inferrable' information; however, not every mill has a pond: wind mills do not! In any case, we are left with a ST presupposition which is not rendered as such in the translation which means that TT readers will have to do less inferencing than ST readers, on this occasion.

Not only is the pond presented, in the ST, in a way which suggests it is already known to readers, but, in actual fact, in the Romanian 'the pond' is introduced in the narrative before the mill itself (English word order differs from Romanian and literally reproducing it in the gloss has resulted in a very awkward sentence), and carries the first definite article of the narrative. As can be seen later in the story, the pond is the centre of evil around which events revolve, and the way it is presented in the opening paragraph is not without significance for the overall development of the narrative. In the translation, the focus is shifted onto the mill.

Further evidence of [- definite] shifting can be seen in (2), and here the shift takes place in the very title of a story. Seven Wooden Horns, by Dominic Stanca, is part of a series of short stories recounting episodes from the everyday life of the mountain people who knew Avram Iancu and shared his struggle to obtain legal rights for the Transylvanians, who were at that time under Austro-Hungarian rule. It is the only one of the series to be translated into English, in the volume History and Legend in Romanian Short Stories and Tales. The Romanian word for wooden horn is tulnic and in Stanca's writings it acquires the status of a central symbol which reinforces the coherence of the series and appears in the title of several short stories (Tulnicul lui Gădălin - Gădălin's Wooden Horn, Tulnicele Iancului - Iancu's Wooden Horns). 
(2)

ST: Cele şapte tulnice (Stanca 1981: 102)

Gloss: The seven wooden horns

TT: Seven Wooden Horns (Stanca 1983: 267)

The original title appears to convey a message along these lines: we all know about the seven wooden horns, and this story will be about them. On the other hand, the translation reads: there are some wooden horns, and this story will be about seven of them. The Romanian gives the impression that the writer assumes (or behaves as though he assumes) that readers are aware of the existence of the seven wooden horns before reading the story and that, upon encountering the title, they will immediately be able to bring this awareness to their reading of it. This is because, as recommended in grammars of Romanian (and English), definiteness shows that the reality designated by the noun is (assumed to be) known to the speaker and hearer (Daniliuc and Daniliuc 2000: 46). Definite reference in the title of the story claims familiarity with the entities which are the subject of the story, and suggests that, while the narration will enhance the audience's awareness by presenting new and relevant information, the existence of the entities can be taken for granted (presupposed) from the outset and is 'common ground' (Brown and Yule 1983: 29) for the participants in the conversation. However, this explanation is not entirely satisfactory because, as will be shown, presuppositions can be used for various other reasons besides presupposing awareness of the items designated.

The question which arises at this point is: what is the reason for the presupposition in the title? The most straightforward explanation would be the one mentioned above, namely that the original writer assumed his readers to be familiar with the existence of the wooden horns: perhaps they are part of the cultural background readers are expected to have (if this is the case, it should, however, be noted that their significance is likely to be local rather than national, and that it would be unusual if the writer assumed even his Romanian readers to be aware of the wooden horns). If the translator perceived this presupposition as linked to assumptions of Romanian cultural background, it is possible that her intervention in the title and the [- definite] shift are tailored for an audience which was assumed not to share the cognitive environment (to use Sperber and Wilson's 1986 term) which would enable them to recover the interpretation. This would be a delicate balancing act based on (warranted or unwarranted) assumptions about both ST and TT audiences (and about the writer's assumptions and intentions). As pointed out by Fawcett (1998: 120-1), it is frequent that ST audiences themselves, as well as the translators, do not possess the awareness the author of the original assumed them to have and at times even authors forget some of the information they presuppose. Therefore, the extent to which target audiences share the cognitive environment required by the text, and even form an opinion about what context the original requires, is by and large a matter of making assumptions about assumptions. It is possible that the shift in (2) is due to a translator assumption which is different from the assumption the original writer made at that point.

There is an alternative to the interpretation above, and it involves moving away from the view that 'the horns' is a straightforward presupposition. It has already been shown that it is unlikely source text readers were really expected or believed to have previously been aware of the wooden horns. If this is the case, the writer appears to 
be flouting Grice's maxim of quantity, by not being as informative as required. Or could it be that the information is not really needed, because something else is going on in the title? Perhaps nothing is really presupposed in ST (2) except the readers' willingness to co-operate and become 'authorial accomplices' (Mey 2000: 346); a make-believe presupposition is present, giving the appearance of a presupposition but actually acting as an invitation to enter the genre convention (see the similarity of this with Snow White and the Seven Dwarves) and taking the definiteness (and thereby the existence of the entity it designates) for granted. The fact that readers are generally not confused by such usage and know how to react to it means that it would occur to very few people reading the title Snow White and the Seven Dwarves to inquire, which dwarves are you talking about?

In view of the arguments above, it appears that the [- definite] shift in the translation of (2) is not required by conventions of genre and, most probably, neither is it triggered by considerations of a different cognitive environment (i.e., cultural background) in the TT as compared to the ST.

Fawcett (1998: 120) argues that the ways in which translators handle presupposition may be seen as 'acts of provocation,' and this can be interpreted in at least two different ways: that readers are challenged into participation by creating the need for extra processing effort on their part, and secondly, that they are provoked to overlook the potential threat to their negative face involved in presupposing a sharedness which may not be the case. Indeed, it is conceivable that by presupposing rather than supplying information, especially in cases such as ST (2) where it seems that readers will not really share the presupposed awareness, and within the literary genre which validates this usage, the Romanian title Cele şapte tulnice endeavours to provoke engagement with the narrative, and this may be part of the (deliberate or non-deliberate) strategy of the original writer. Readers are welcomed from the outset into the in-group of persons (accomplices!) who know about the wooden horns, and to whom the narrator belongs; they are not required to wait till they have read the story to obtain in-group membership. Complicity and closeness (not unlike those triggered by the use of proximal deictics, see Mason and Şerban 2003) is thus established between writer and audience, and it is precisely this kind of relationship that the [- definite] shift in the translation diminishes with its more objective approach, which takes for granted less 'common ground' with readers.

Isolated occurrences can be meaningful but do not in themselves support a claim that translating definite references as indefinite references is important in the overall picture provided by the translations. This is why, in what follows, we examine three sets of examples in order to better observe how the effect of [- definite] trend builds up in a text and gains significance with each new instance. The first set we look at is from Seven Wooden Horns, the short story from which (2) was also taken.

(3)

a) ST: Pe drumul rîpos care suie către Buciumele cele şapte, între străjile de piatră ale munţilor, în susul firului de apă, trecea cu pas bătrîn şi poticnit un creştin [...]. (Stanca 1981: 102)

Gloss: On the steep road which goes up to the seven Buciums, between the watchful stony mountains, up the stream, a Christian man was passing with old and stumbling walk [...]. TT: Up the steep road to the seven Bucium villages, between the stony, watchful mountains along a tiny stream, a man [...] was trudging, tired and stumbling in his walk. (Stanca 1983: 267) 
b) ST: [...] n-avea nici straiţă, nici ciubere, ci numai fluierul din care zicea. Ce zicea îl pricepeau poate munţii cu urechi de piatră, deprinse din încrîncenarea celor două bătălii să ia aminte la chemarea tulnicelor la judecata cea dreaptă [...]. (Stanca 1981: 102)

Gloss: [...] had neither bag nor tubs, but only the pipe he was singing from. What he was singing perhaps the stone-eared mountains could understand, as they had learnt from the fierceness of the two battles to listen to the wooden horns' summons for the just judgement. TT: [...] had neither bag nor tub, but just the pipe that he was fingering. What he meant to say, the stone-eared mountains alone may have understood, for the calamity of the two battles had taught them to mind the call of the wooden horns for a just verdict. (Stanca 1983: 268)

Example (3a) is reproduced from the opening of the short story and sets the scene of the narrative. The definite reference in the ST title (see example 2), which can serve to guide reading and suggest that (make-believe) familiarity with part of the characters, events and places is presupposed, is taken up in (3) by a series of presuppositions: 'drumul' (the road), 'Buciumele cele şapte' (the seven Buciums), 'străjile de piatră ale munţilor' (the watchful stony mountains), 'firului de apă' (of the stream) which describe a location which is, allegedly, known to the audience. In contrast with this presupposed familiarity with the landscape is the human presence, which is introduced at this point by the indefinite 'un creştin' (a Christian man). In fact, not presupposing the existence of the man while presupposing familiarity with the scenery does not necessarily refer to information which readers already possess or may possess, but to something which is treated as being real in the context and, as such, a guiding device encoding a preferred reading. According to Hickey et al. (1993: 81), this use of presupposition is frequent in literary fiction and readers tend to go along with the presuppositions they encounter and perceive them as vital for what is communicated to make sense. It is rare for such presuppositions to be questioned (Yule 1996: 29).

Most definite references in (3a) are translated as such, preserving the existential presuppositions, but there is one shift from 'firului de apă' (of the stream), to 'a stream.' Mountains usually have streams and consequently the ST existential presupposition is linked to the category of 'inferrables' involving 'stereotypic assumptions' (Prince 1981: 242). Not only Romanian mountains have streams; an English-speaking audience should be equally able to make the inference required in the original text, but the need to do so is weakened in the translation. Since there is no obvious reason why "the stony mountains" should be presupposed in the translation but the definite reference to the stream should be shifted to an indefinite reference, it is reasonable to suggest here that presupposing is not necessarily a matter of what the audience can actually be assumed to be aware of, but, rather, a matter of how a writer or translator chooses to present things.

Example (3b) presents yet again a series of ST presuppositions by definite description which are translated as such, with one exception: 'judecata cea dreaptă' (the just judgement) rendered as ' a just verdict.' Shifts add up, and on the first page of the short story there already are at least three [- definite] shifts.

'Judecat a cea dreaptă' is a biblical reference which creates a symbolic comparison between the expectation of a better world in the hereafter and the mountain peasants' struggle for justice in this world, and in-group awareness is needed to understand it. The translation removes the (assumed) familiarity which the original text 
seeks to provoke and, instead, a neutral and juridical term ('a just verdict') is used. It is possible that this usage is indicative of and conducive to a lesser degree of involvement in the story, in a similar way to the distancing triggered by the use of some distal deictics (see Mason and Şerban 2003). Interpreting the shift as being linked to a cultural presupposition (in view of the fact that it may be due to the translator's assumption that target readers would not readily be able to understand the reference) rather than as a presupposition triggered by definiteness, does not diminish the distancing because, either way, in-group awareness is no longer such an imperative. It is important to consider that in actual fact the background context required to decode the ST presupposition in (3b) is one of Christian heritage, which both source and target cultures share.

Interesting instances of non-shifting can be seen in 'the calamity of the two battles' (3b), where no indication whatsoever is given as to what battles are alluded to. This is probably a case of cultural presupposition manifesting itself via definite description, because the two battles are not a figment of the narrator's imagination but, as source text readers might be aware, they were real life confrontations. It is puzzling to notice that the translator, while shifting 'the just judgement' into 'a just verdict,' does not consider it necessary to supply (perhaps in a footnote) target readers with information they are less likely to share. On the other hand, 'Buciumele cele şapte' (the seven Buciums) in (3a) does preserve the existential presupposition triggered by the definite article but an explicitation ('the seven Bucium villages') is present in the translation to tell readers that the Buciums are villages and not, for instance, mountains or rivers. (For a discussion of cultural presuppositions in the Romanian-English literary corpus, see Şerban 2003)

The dynamics involved in translating definites and indefinites can be also be noted in (4), in a set of three excerpts taken from the first chapter of the novel Baltagul (The Hatchet). Baltagul is situated at the crossroads between detective, psychological writing, and traditional rural literature, and most Romanian readers would probably find it easy to recognise this novel as a reworking of the theme in the ballad Mioriţa, particularly as two lines from the ballad are quoted at the very start of the ST (intertextuality), and guide reading. Target readers are clearly not expected to bring to the text an awareness of this ballad, as the quotation is not reproduced in the translation.

A peasant woman from the Moldavian mountains embarks on a journey to find her disappeared husband or punish his murderers, as she suspects he was killed and that the flocks of sheep he was travelling with were stolen. Comparing the definiteness in the ST and TT title of this novel with the [- definite] shift in the title of the short story in (2) and (3) gives an indication of the range of alternatives often available in translating, which result in titles such as Seven Wooden Horns on the one hand, and The Hatchet (4) on the other. The excerpts below depict the routine of everyday life in the mountains, before Vitoria Lipan decides to start her journey.

(4)

a) ST: Se auziră pe drumuşor talănci cunoscute. Venea Mitrea argatul cu cîrdişorul de oi şi cu cele două vaci. (Sadoveanu 1987: 94)

Gloss: Familiar bells were heard from the narrow road. Mitrea the farm-hand was coming with the little flock of sheep and the two cows.

TT: The sound of familiar cattle bells was heard from the narrow road. Mitrea, the farm-hand, with a few sheep and two cows, was coming along it. (Sadoveanu 1983: 20) 
b) ST: Stăpîna strînse din umeri. Omul se aşeză mormăind pe colţul prispei. (Sadoveanu 1987: 95)

Gloss: The mistress shrugged her shoulders. The man sat down grumbling in the corner of the verandah.

TT: The housewife shrugged her shoulders, and the man, mumbling something, sat down in a corner of the verandah. (Sadoveanu 1983: 22)

c) ST: [...] o privi deodată un pui cenuşiu de mîţă, cu ochi rotunzi [...]. Minodora puse lîngă fărmături scăfița ştirbă şi turnă în ea cîteva picături de lapte. (Sadoveanu 1987: 98)

Gloss: [...] suddenly a grey kitten looked at her, with round eyes [...]. Minodora placed the chipped bowl by the crumbs and poured a few drops of milk into it.

TT: $[\ldots]$ a grey kitten looked at her with rounded eyes [...]. Minodora set a broken bowl on the floor by the crumbs and poured a little milk into it. (Sadoveanu 1983: 26)

"Cîrdişorul de oi" (the little flock of sheep) is 'textually evoked' by "familiar bells" which, in the countryside, usually signal the approach of cattle or sheep. In the translation, it is rendered as "a few sheep," "cele doua vaci" (the two cows) is translated as "two cows," and "the corner of the verandah" is "a corner of the verandah." Along the same lines, the familiar chipped bowl (the chipped bowl, none other) which Minodora uses to feed the kitten is translated as "a broken bowl," that is, any broken bowl. These are all familiar objects in Vitoria's world, and referring to them via definiteness in the original is suggestive of the narrator's psychological involvement (similar to deictic projection). Other [- definite] shifts in the novel add to the trend (e.g. 'Suddenly the wind passed rustling' $\rightarrow$ 'Suddenly a wind rustled,' 'The/her chestnut wisps of hair strayed [...]' $\rightarrow$ 'Stray wisps of chestnut hair'). The difference between ST and translation is one of degree, because in actual fact indefinite reference can also trigger presuppositions, although of a weaker kind (e.g. "set a broken bowl on the floor" presupposes that a bowl exists in the household, but is weaker than "placed the chipped bowl on the floor" which, besides presupposing that a chipped bowl exists in the room, signals a specific chipped bowl and claims that readers are aware of it).

While a number of definites are shifted in translating, others are not. In (6a) 'the narrow road' is presupposed in both ST and the translation. The definite article in 'the crumbs' (in 4c), however, is not a case of existential presupposition because the crumbs are mentioned in the preceding sentence, which is not reproduced here (i.e., they are 'textually evoked').

We conclude our analysis of [- definite] shifts with a set of two examples from the novel Un om intre oameni (A Man amongst Men) by Camil Petrescu.

(5)

a) ST: [...] lămureşte la rîndul ei femeia legată cu o basma pe subt fălci, ţinînd de mînă fata. (Petrescu 1982: 388)

Gloss: [...] says in her turn the woman with a kerchief tied under her chin, holding the little girl by the hand.

TT: The woman who spoke had a kerchief tied under her chin and held a little girl by the hand. (Petrescu 1958: 407)

b) ST: Tiţa se frînge din nou, privind verigheta înapoiată. Scoate apoi încet de pe deget cealaltă verighetă, dată de el, o priveşte îndurerată şi o pune pe masă. Moale, se prăbuşeşte în fotoliu, subt ochii mamei ei. (Petrescu 1982: 385) 
Gloss: Tița is again shattered, looking at the returned engagement ring. She then slowly takes off her finger the other engagement ring, given by him, looks at it in sorrow and puts it on the table. Weak, she collapses in the armchair, under her mother's eyes.

TT: [...] laid the ring on the table, the sight of which again tore at the poor girl's heart. Slowly she took her own ring from her finger, the ring he had given her, looked at it in sorrow and laid it on the table. Then she fell weakly into a chair, before the eyes of her helpless mother. (Petrescu 1958: 405)

Although mentioned for the first time (i.e., 'brand-new'), the little girl in (5a) is presented in the ST as already familiar, while the translation uses an indefinite. Example (5b) is an interesting one, as so many different things take place: the verbal tense framework is shifted from the present into the past, and there is evidence of translator appraisal (e.g. the addition of 'helpless'). However, what we are interested in here is the ST definite reference 'in fotoliu' (in the armchair), which is translated by an indefinite reference, 'a chair.' The definite article which is used in the original suggests that not only is there an armchair in the room (which, although mentioned for the first time in the narrative, could still be 'inferrable' as it involves the stereotypic assumption that European houses have chairs or armchairs in them) but that either there is just one armchair in the room (the number is not 'inferrable'), or that Tiţa collapses into a particular armchair which could be manifest only to somebody present at the scene, or somebody who has insider awareness of events or Zinca's house. Thus, definiteness in the ST positions the reader, in an almost deictic way, as being present when the events unfold. Other instances of [- definite] shifting in the same translation are: "Moale, se prăbuşeşte în fotoliu [...]" (Weakly, she falls into the armchair) $\rightarrow$ "Then she fell weakly into a chair" (and the verbal tense shifts from historical present to past narrative), and "Pe laviţa de la poarta de lemn [...]" (On the bench near the wooden gate) $\rightarrow$ "[...] upon a bench by the wooden gate [...]."

The examples we have looked at so far mainly deal with [- definite] shifting in the corpus; we now look at a counter-example to the main trend. Example (6) below is the title of a short story about bee-folds, good and bad beekeepers, about coming to age and facing life.

(6)

ST: Prisacă de altădată (Sadoveanu 1955: 297)

Gloss: Bee-fold from long ago

TT: The Old-time Bee-fold (Sadoveanu 1958: 285)

Example (6) is the reverse of what we found in (2), where 'The Seven Wooden Horns' became Seven Wooden Horns. In (6) the target text readers are assumed to be in-theknow with respect to which particular bee-fold is being referred to (as opposed to the readers of Seven Wooden Horns, who are, the translation seems to suggest, not expected to be familiar with the horns). On the other hand, the use of the definite (rather than the indefinite) article in the title of a literary work is a convention of the genre; indeed, the definite reference in the TT title is not unexpected (cf. Snow White and the Seven Dwarves). A foreignising translation strategy would have involved preserving the unusual, marked ST form as a valuable feature in this text; removing markedness and using a conventional 'repertoreme' (Toury 1995: 268) can be interpreted as evidence of domestication and normalisation in translation. In any case, example (6) and other counter-examples to the [- definite] trend, which for reasons 
of space could not be reproduced here, suggest that translators have considerable freedom to decide whether to use definiteness or indefiniteness. This makes texts an even more valuable resource for the researcher because, as Beaugrande and Dressler (1981: 35) point out, "many occurrences are significant by virtue of other alternatives which could have occurred instead." Texts are documents of decision and selection, and, according to Brown and Yule (1983: 26), "the record of a dynamic process in which language was used as an instrument of communication."

\section{Conclusions}

The numerical findings presented in section 3 show that there is considerably more shifting in the direction of [- definiteness] than in the direction of [+ definiteness], which means that more existential presuppositions are removed from than added to the texts in the corpus, via translating. Although there is one exception to this trend (sample 8), the systematic presence of [- definiteness] in the rest of the corpus is nonetheless striking. The pragmatics-oriented analysis in section 4 , where examples are explored in their co-text, suggests that the [- definite] trend in the translations in the corpus involves claiming less common ground with readers, less involvement in the narrative, less complicity, and hence leads to distancing, by comparison with STs. Since analysis demonstrates that such shifts frequently occur in circumstances where it can reasonably be claimed that what is really assumed in the ST is not a specific piece of information, but, rather, the readers' co-operation and readiness to consider themselves part of the same in-group as the author, it becomes clear that shifting redraws boundaries between participants on the one hand, and participants and text on the other. Thus, the [- definite] trend in existential presuppositions acts towards positioning readers in a particular way which is different from the way in which ST readers are positioned: TT readers are distant observers, rather than informed ingroup members. The study does not claim that source texts are characterised by overall approximating and translations are characterised by overall distancing; rather, it is argued here that a systematic distancing discourse is introduced in translation and that this is a matter of degree, rather than of absolute presence or absence of distancing.

Writers have their assumptions about the world, and in particular about readers, the act of writing, or genre conventions. On the other hand, translators bring to the task their own creativity, and a set of assumptions which may on some occasions coincide with those of the writer while on others there can be considerable differences. This interplay of coincidences and differences may to an extent explain why certain presuppositions are shifted and others are not. The existence of a [- definite] trend in the corpus points to the fact that less is taken for granted in the translations, compared to the source texts, although the extent to which this happens differs from one translator to another, as well as from one target text to another, and may also be linked to the frequency and type of existential presuppositions which are present in the ST in the first place. The peculiar circumstances of the translations analysed here (performed into English by native users of Romanian in Romania, during a period of cultural isolation and consumed almost exclusively within that culture) are probably linked, in some way, to the presence of the [- definite] trend. For example, it is possible that Romanian translators were not confident about their target readers' will- 
ingness to take things for granted, as it were, and hence indefinite references (which presuppose less, and therefore are less demanding) may have seemed a safer option. It is also possible that the Romanian translators, working within the then Communist Romania, felt distanced from their Western audience and, in their translations, accommodated to what they perceived to be boundaries between themselves and readers. At the same time, the [- definite] trend might be linked to the translators' self-positioning towards the text, the ideas expressed, the characters which are presented or the events which are narrated. After all, translators do have a voice of their own, and it manifests in the text in the choices they make between viable alternatives.

This study has focused on existential presuppositions triggered by definite and indefinite reference, and has focused on cases of definiteness translated as indefiniteness (which have been shown, by the numerical findings in section 3 , to constitute the main trend in the corpus). It would be interesting to also explore instances of ST definiteness or indefiniteness translated by a proximal or a distal demonstrative (e.g. this or that), and, conversely, cases where ST proximals or distals are translated using articles instead. After all, Levinson's (2000: 94) hierarchy of givenness (see discussion in section 1) places indefinite and definite articles, and demonstratives, on the same scale: starting from the left, and proceeding to the right, he allocates them different positions according to the degree to which their referents are (assumed to be) mentally activated. This will be the subject of a subsequent project.

\section{NOTES}

1. This corpus is part of a larger corpus which also comprises translations by native speakers of English, published in the UK, and translations by Romanian/English-native teams of translators. The size of the larger corpus is twenty-three books; for a comprehensive analysis of deixis and presupposition in samples from the entire corpus, see Şerban (2003).

2. The same pattern, although manifesting in a weaker way, was found to be in operation in translations from Romanian by native speakers of English (see Şerban 2003).

3. Many of the source texts which were used for analysis are later editions of the original texts.

\section{REFERENCES}

Beaugrande, R. De and W. Dressler (1981): Introduction to Text Linguistics, London and New York: Longman.

Brown, G. and G. Yule (1983): Discourse Analysis, Cambridge: Cambridge University Press.

Daniliuc, L. and R. DAniliuc (2000): Descriptive Romanian Grammar, Muenchen: LINCOM EUROPA.

Fawcett, P. (1998): “Presupposition and Translation,” In L. Hickey (ed.) The Pragmatics of Translation, Clevedon: Multilingual Matters.

Graur, A. et al. (1966): Gramatica limbii române vol I and II, Bucureşti: Editura Academiei RSR.

Hickey, L., R. Lores, H. Loya Gomez and A. G. de Carrasco (1993): "A Pragmastylistic Aspect of Literary Translation," In Babel 39 (2), 77-88.

Leech, G. (1989): An A-Z of English Grammar and Usage, London: Edward Arnold.

Levinson, S. C. (1983): Pragmatics, Cambridge: Cambridge University Press.

Levinson, S. C. (2000): Presumptive Meanings. The Theory of Generalized Conversational Implicature, Cambridge Massachusetts: The MIT Press.

Mason, I. and A. ŞERban (2003): "Deixis as an interactive feature in literary translations from Romanian into English,” In Target 15-2, p. 269-294.

Mey, J. L. (2000): When Voices Clash. A Study in Literary Pragmatics, Berlin: Mouton de Gruyter. 
Prince, E. F. (1981): “Toward a Taxonomy of Given - New Information,” In P. Cole (ed.) Radical

Pragmatics, New York: Academic Press.

Simpson, P. (1993): Language, Ideology and Point of View, London and New York: Routledge.

Sperber, D. and D. Wilson (1986): Relevance. Communication and Cognition, Oxford: Blackwell.

ŞERban, A. (2003): Audience Design in Literary Translations from Romanian into English: A Corpus-

Based Analysis of Deixis and Presupposition, Unpublished $\mathrm{PhD}$ thesis, Heriot-Watt University.

Toury, G. (1995): Descriptive Translation Studies - and Beyond, Amsterdam: John Benjamins.

Yule, G. (1996): Pragmatics, Oxford: Oxford University Press.

\section{Primary texts ${ }^{3}$}

Galaction, G. (1979): "Moara lui Călifar,” In N. Ciobanu (ed.) Antologie de proză scurtă românească, De la Constantin Negruzzi la Pavel Dan, Bucureşti: Editura Minerva, 160-9.

Galaction, G. (1981): “Călifar’s Mill,” In Romanian Fantastic Tales, Bucharest: Minerva Publishing House, 48-56, Transl. by A. Cartianu.

Petrescu, C. (1958): A Man amongst Men, vol. 1, Bucharest: Foreign Languages Publishing House. Transl. by E. Farca; verses transl. by D. Duţescu.

Petrescu, C. (1982): Un om între oameni, In C. Petrescu Opere IV, Bucureşti: Editura Minerva.

SAdoveanu, M. (1955) : "Prisacă de altădată," In M. SAdoveAnu Opere IV, Bucureşti: Editura de Stat pentru Literatură şi Artă, 297-304.

Sadoveanu, M. (1958): “The Old-time Bee-fold,” In Evening Tales, Bucharest: Foreign Languages Publishing House, 285-92. Translators' name not mentioned; probably E. Farca, L. Marinescu, S. Radu, and V. Alexandru.

Sadoveanu, M. (1983): The Hatchet, Bucharest: Minerva Publishing House. Transl. by E. Farca.

Sadoveanu, M. (1987): Baltagul. In M. Sadoveanu Hanu Ancuţei. Baltagul, Bucureşti: Editura Minerva, 88-199.

Stanca, D. (1981): “Cele şapte tulnice," In D. Stanca Timp scufundat, Bucureşti: Editura Eminescu, 102-6.

Stanca, D. (1983): “Seven Wooden Horns," In History and Legend in Romanian Short Stories and Tales, Bucharest: Minerva Publishing House, 267-72. Transl. by A. Cartianu. 